\title{
Feeding dynamics of fish larvae on Copepoda in the western Irish Sea, with particular reference to cod Gadus morhua
}

\author{
A. B. Thompson, R. T. Harrop \\ MAFF, Directorate of Fisheries Research, Pakefield Road, Lowestoft, Suffolk NR33 0HT, England
}

\begin{abstract}
Cod and other species of fish larvae, and nauplii and copepodite copepods, were sampled in the western Irish Sea in April/May 1988 and 1989. The diet of cod larvae was determined by gut analysis, and consisted almost entirely of copepods. The daily energy requirements of 3 sizes of cod larvae were determined from modified forms of published energetic models, and used to estimate numbers of copepods eaten per larva per day. The volume of water searched by larvae is modelled as a power function of larvae length. Modelling predictions indicate that cod larvae of $<5 \mathrm{~mm}$ length require high densities of copepod nauplii as they can search only small volumes of water. Larger larvae, $\geq 7.5 \mathrm{~mm}$ length, consume large numbers of copepodites and so require high densities of copepods to avoid depletion of the food resource. Observed copepod densities were sufficient for the energy requirements of the cod larvae populations at the densities observed in the western Irish Sea. However, when all species of larvae are considered, the model predicts that competition for food is likely to occur among larger larvae at observed copepod densities.
\end{abstract}

\section{INTRODUCTION}

Are fish larvae too dilute to affect, and be affected by, their food supply? Cushing $(1983$, p. 853) concluded that haddock 'are probably too dilute during the early larval phases to affect their food but as the larvae grow this tendency is reversed and larvae progressively have more and more effect on their food'. Bollens (1988) agreed that larvae would significantly reduce prey populations, but thought that the impact would be greatest when the larvae were very small. Dagg et al. (1984), investigating walleye pollock Theragra chalcogramme, and Peterson \& Ausubel (1984), investigating Atlantic mackerel Scomber scombrus larvae, also agreed that larvae could significantly affect prey numbers. Under such circumstances, a relationship should exist between the density of fish larvae and their food.

This paper details a study, undertaken in the western Irish Sea during 1988 and 1989, which determined densities of fish larvae and copepods in regions of mixed and stratified water (Fogg et al. 1985). Although all species of fish larvae were counted, particular emphasis was placed on cod larvae and their food requirements over 3 size ranges. The diet of cod was determined and found to consist almost entirely of copepods.

The study mainly determined the number and density of copepods required in the diet of fish larvae to satisfy their daily energy requirements of growth and maintenance. This was undertaken using a modified form of the bioenergetic feeding models developed by Laurence (1982), Cushing (1983), Checkley (1984), and Kiørboe et al. (1987) and was used to examine the relationship between fish larvae (the predator) food requirements and copepod (the prey) density over a range of fish larvae lengths. These models looked at the daily energetic requirements of active, growing larvae. A knowledge of the energy content of the diet of larvae was used to convert energy rquirements of larvae to estimates of numbers of prey items eaten per day.

Two questions emerge regarding conditions that must be satisfied in order for larvae to survive:

(1) What copepod density is required so that daily requirements of larvae can be satisfied within the volume of water searched? This is a threshold density, below which larvae cannot find enough food to sur- 
vive under the conditions specified by the feeding model.

(2) What copepod density is required so that their populations do not decline when being harvested by the fish larvae population? This is examined, using a stage-structured model modified from Bollens (1988), to determine the population dynamics of copepods suffering predation by fish larvae. This provides a 'steady-state' copepod density for a given size and number of larvae, under the conditions specified by the models, so that the copepod density is neither increasing or decreasing under fish larvae predation.

These questions are examined for cod larvae over a range of densities and sizes, to determine food densities required for survival under a given set of conditions. The investigation was further extended to include all species of larvae found in the western Irish Sea in order to investigate multi-species effects.

\section{MATERIALS AND METHODS}

Sampling at sea. Plankton samples were collected in the western Irish Sea from 47 stations during 24 April to 2 May 1988 and from 36 stations during 16 to 20 April 1989 (Fig. 1), using the MAFF research vessel RV 'Cirolana'. The Lowestoft Gulf III High Speed Tow Net (HSTN) fitted with a $270 \mu \mathrm{m}$ aperture mesh main net was deployed to collect fish larvae, and a $35 \mu \mathrm{m}$ aperture fine mesh net to collect copepods (Milligan \& Riches 1983). The sampler was towed at 5 knots in a double oblique haul from the surface to within $1 \mathrm{~m}$ of the sea bed and back to the surface. The main net was fitted with a flow meter which was calibrated to measure the volume of water passing through the $0.40 \mathrm{~m}$ diameter mouth opening of the nose cone. The fine mesh net has a nose cone diameter mouth opening of $0.05 \mathrm{~m}$, but was not fitted with a flow meter. The volume of water passing through the fine mesh net was calculated from the volume passing through the main net divided by 64 , which was the ratio of their respective nose cone mouth opening areas. Nichols \& Thompson (in press) showed that a $55 \mu \mathrm{m}$ mesh net filters $60 \%$ of the volume of a $270 \mu \mathrm{m}$ mesh net, so the volume filtered by the fine mesh net was reduced accordingly. The samples of fish larvae and zooplankton were preserved with buffered $4 \%$ formalin. Additional qualitative samples of cod larvae were collected in the western Irish Sea in 1988 and 1989 by towing the HSTN at 3 to 4 knots. These were frozen in seawater and subsequently used for dry weight determination and stomach contents identification.

Laboratory analyses. The density of copepods (numbers per litre), and cod larvae and total larvae (numbers $\mathrm{m}^{-3}$ ), were calculated for all stations. The total length, to the nearest $0.1 \mathrm{~mm}$, of all cod larvae collected in the calibrated main net samples was also determined. Additionally, copepod cephalothorax lengths (from anterior to posterior end of the cephalosome) were measured from the 47 samples collected by the fine mesh net in 1988 . This was determined by taking a subsample of known volume of ca 100 copepods from the sample with a Stempel pipette and counting, measuring the cephalothorax length, and identifying the copepodites to genus under a microscope. Nauplii were counted and measured, but not identified.

The qualitative samples of frozen cod larvae were thawed and the total length to $0.1 \mathrm{~mm}$ of each larva measured. The gut was dissected out under a lowpower microscope, the contents identified, and the number and cephalothorax lengths of all copepods recorded. It was assumed that this was representative of the size range of copepods eaten by different sizes of cod larvae, and also assumed that all prey sizes were digested at the same rate. Other food items were recorded.

Cod larvae collected in 1989 were measured, dried in an oven at $60^{\circ} \mathrm{C}$ for $24 \mathrm{~h}$ and weighed to the nearest $0.01 \mathrm{mg}$.

Weight of copepods eaten by a cod larva per day. A modified form of Cushing's (1983) model was used to estimate the dry weight of food required by a fish larva per day $\left(\mathrm{W}_{\mathrm{F}}, \mu \mathrm{g}\right)$ as a function of the dry weight $\left(\mathrm{W}_{\mathrm{L}}, \mu \mathrm{g}\right)$ and daily dry weight increase $\left(\Delta \mathrm{W}_{\mathrm{L}}, \mu \mathrm{g}\right)$ of the larvae,

$$
\mathrm{W}_{\mathrm{F}}=\frac{\Delta \mathrm{W}_{\mathrm{L}}+\mathrm{K} \mathrm{q} \mathrm{W}_{\mathrm{L}}^{\mathrm{n}}}{\mathrm{a}} \text {. }
$$

The constant $\mathrm{K}$ is 1.1 at $10^{\circ} \mathrm{C}$ (Beyer \& Laurence 1980), the exponent $\mathrm{n}$ is 0.671 (Laurence 1978), and $\mathrm{q}$ is a temperature $\left(\mathrm{T},{ }^{\circ} \mathrm{C}\right)$ dependent coefficient which has been added here, such that

$$
q=2.3^{\left(\frac{T-10}{10}\right)}
$$

(Brett \& Croves 1979). The assimilation efficiency of ingested food, $a$, is set to 0.5 . This is close to the asymptotic value of 0.48 used by Cushing (1983), and agrees with Boehlert \& Yoklavich (1984) who determined assimilation values of 0.39 to 0.68 for herring

Fig. 1. Densities of copepods and fish larvae in the western Irish Sea from 24 Apr to 2 May 1988 (left) and from 16 to 20 April 1989 (right). Bubble densities for (a) to (d) are $<0.1,1-10$, and $>101^{-1}$; for (e) and (f) are $<0.01,0.01-0.05$, and $>0.05 \mathrm{~m}^{-3}$; and for (g) and $(\mathrm{h})$ are $<1,1-5$ and $>5 \mathrm{~m}^{-3}$. Bubble sizes are directly related to ranges given. The bound area on Fig. $1 \mathrm{a}$ represents a region of stratified water where surface to bottom temperature differences exceeded $1{ }^{\circ} \mathrm{C}$. This feature was not seen during sampling in 1989 

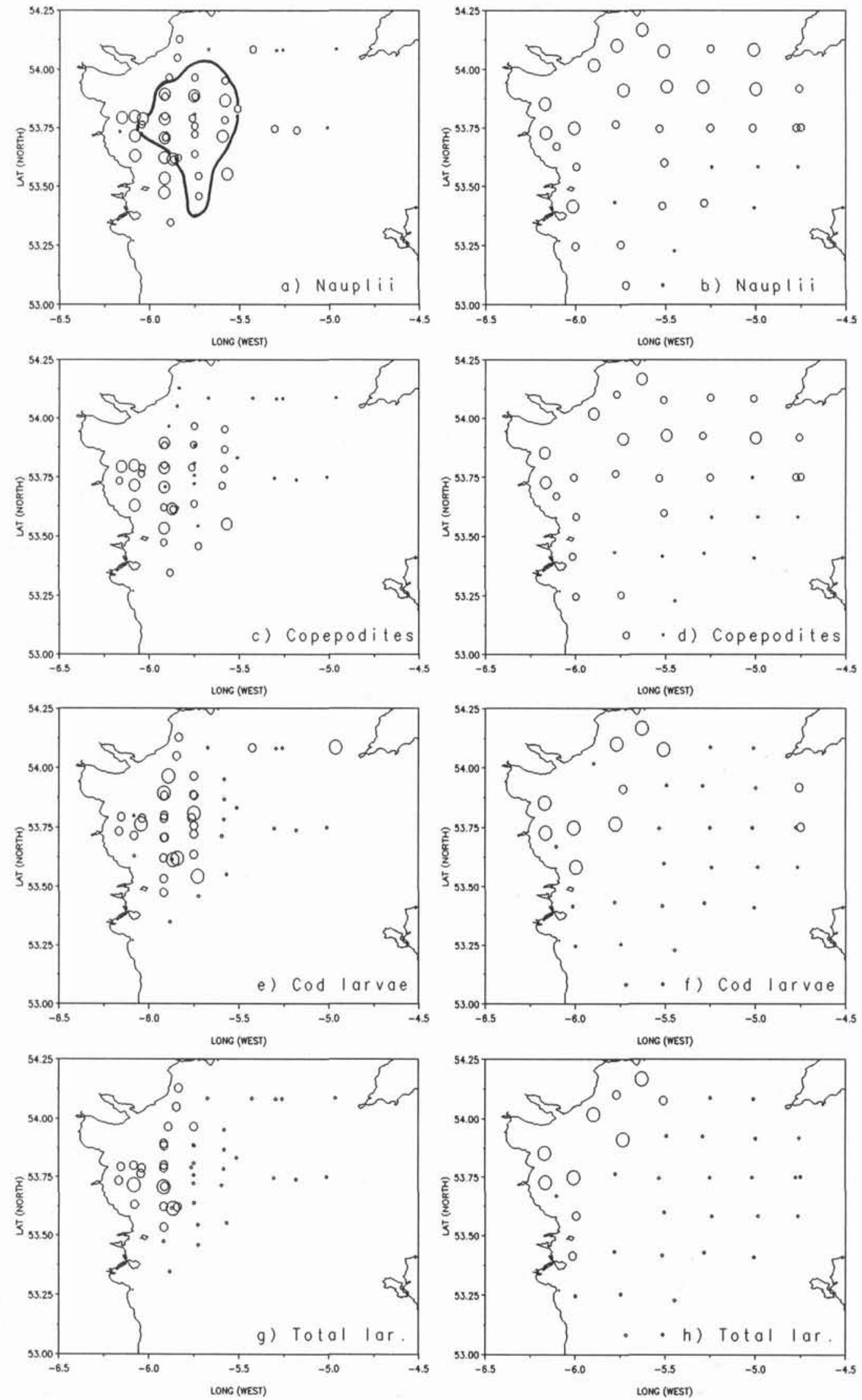
larvae, depending on the ingestion rate. Buckley \& Dillmann (1982) found a size-related assimilation efficiency based on an analysis of nitrogen uptake which increased food requirements by over 3 -fold for small larvae. Cushing (1983) included this in his analysis; however, such an effect was not found by Kiørboe et al. (1987) and is not included here.

Copepod density required to support a single cod larva. It is assumed that copepods reproduce at a rate dependent upon the fecundity of the mature egg-laying females $(\mathrm{F})$ in the population, and die only by being eaten by cod larvae. In this model, the copepods suffer no other form of mortality. The copepod population is divided into nauplii, immature copepodites, and mature copepodites. A Leslie projection matrix is used to model the copepod population, and follows similar lines to Bollens (1988). The number of nauplii $\left(\mathrm{N}_{\mathrm{n}}\right)$, immature copepodites $\left(\mathrm{N}_{\mathrm{i}}\right)$, and mature copepodites $\left(\mathrm{N}_{\mathrm{m}}\right)$, on day $\mathrm{t}$, is

$$
\left(\begin{array}{l}
N_{n}(t+1) \\
N_{i}(t+1) \\
N_{m}(t+1)
\end{array}\right)=\left(\begin{array}{ccc}
1-P_{n} & 0 & F / 2 \\
P_{n} & 1-P_{i} & 0 \\
0 & P_{i} & 1
\end{array}\right)\left(\begin{array}{l}
N_{n}(t) \\
N_{i}(t) \\
N_{m}(t)
\end{array}\right)-\left(\begin{array}{l}
E_{n} \\
E_{i} \\
E_{m}
\end{array}\right) \text {. }
$$

The transition probabilities, $\mathrm{P}_{\mathrm{n}}$ and $\mathrm{P}_{\mathrm{i}}$, determine the proportion of copepods that enter the next stage, and can be approximated by the reciprocal of the stage durations, $D_{n}$ and $D_{i}$, respectively (Eqs. $9 \& 10$ ). This assumes a uniform age distribution within each stage. The duration of the mature copepodite stage is here assumed to be infinite.

The number of copepods in each category eaten by a cod larva per day is included in the projection matrix (Eq. 3) and estimated by apportioning the dry weights of each copepod category to the total dry weight consumed $\left(\mathrm{W}_{\mathrm{F}}\right)$ as estimated from Eq. (1). The total number of copepods eaten per larva per day (R) is

$$
R=W_{F} /\left(\alpha_{n} \bar{W}_{n}+\alpha_{i} \bar{W}_{i}+\alpha_{m} \bar{W}_{m}\right)
$$

where $\alpha_{n}, \alpha_{i}$ and $\alpha_{m}=$ proportions of each category found in the gut analysis, and $\overline{\mathrm{W}}_{\mathrm{n}}, \overline{\mathrm{W}}_{\mathrm{i}}$ and $\overline{\mathrm{W}}_{\mathrm{m}}=$ mean weights of each copepod category derived from the length composition data (Eq. 8). Therefore, the numbers of each category eaten per larva per day is

$$
\begin{aligned}
& E_{n}=R \alpha_{n}, \\
& E_{1}=R \alpha_{i} \\
& \text { and } \quad E_{m}=R \alpha_{m} .
\end{aligned}
$$

A female copepod reproduces in the mature copepodite stage with a daily fecundity $(F)$ of 2.0 , which was taken as an average value for the common copepods found in the Irish Sea during this study (Frost 1985, Dagg et al. 1984). The egg stage was ignored, mainly because it was not common in the diet of Irish Sea cod larvae.
Steady state solutions to Eq. (3) are

$$
\begin{array}{ll}
N_{n} \cdot=\left(E_{m}+E_{i}\right) / P_{n}, \\
\\
N_{i}^{*}=E_{m} / P_{i \prime} \\
\text { and } \quad N_{m} \cdot=2\left(E_{m}+E_{i}+E_{n}\right) / F .
\end{array}
$$

The model is unstable, since perturbations away from the steady state levels cause the copepod population to grow to infinity or die to extinction under constant predation pressure. Therefore, the steady state level can be regarded as the minimum number of copepods in each category that are required to support a single cod larva of known size under specified conditions of temperature and growth, and without being subject to other forms of mortality. Clearly, according to the predictions of the model, if there are more copepods than this, then the cod larva will survive, but if there are less, then larvae will eventually eat out their food supply and die.

Growth rates of cod larvae and copepods. The total length $\left(\mathrm{L}_{\mathrm{L}}, \mathrm{mm}\right)$ to dry weight $\left(\mathrm{W}_{\mathrm{L}}, \mu \mathrm{g}\right)$ relationship of 133 cod larvae collected from the Irish Sea during April and May 1989 was

$$
\mathrm{W}_{\mathrm{L}}=2.5 \mathrm{~L}_{\mathrm{L}}^{2.77} \quad \text { for } \mathrm{L}_{\mathrm{L}}<23 \mathrm{~mm}
$$

(Fig. 2). Preliminary results from a study of otolith rings gave an estimate of daily growth of cod larvae (K. Brander, MAFF, Lowestoft, unpubl.). From the agelength relationship and Eq. (7), cod larvae were found to increase their dry body weight by $10 \% \mathrm{~d}^{-1}$.

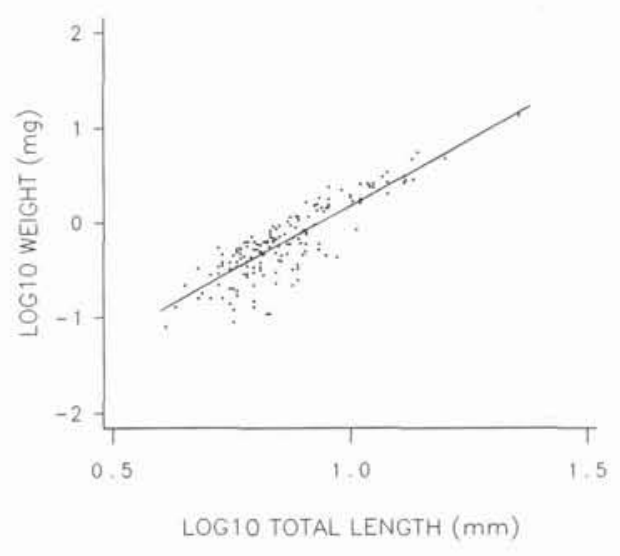

Fig. 2. Gadus morhua. Relationship between dry weight $\left(\mathrm{W}_{\mathrm{F}}\right.$, $\mu \mathrm{g})$ and total length $\left(\mathrm{L}_{\mathrm{F}}, \mathrm{mm}\right)$ of cod collected from the western Irish Sea. $\mathrm{W}_{\mathrm{F}}=2.5 \mathrm{LF}^{2.77}$

A model of copepod dynamics was developed using parameters estimated for Pseudocalanus elongatus (Boeck). The size and stage durations of $P$. elongatus are similar to other copepod species common in the Irish Sea at the time of sampling (Hay et al. 1988). The 
dry weight $\left(\mathrm{W}_{\mathrm{c}}, \mu \mathrm{g}\right)$ to cephalothorax length $\left(\mathrm{L}_{\mathrm{c}}, \mathrm{mm}\right)$ can be approximated by

$$
\mathrm{W}_{\mathrm{c}}=\exp \left(4.964 \mathrm{~L}_{\mathrm{c}}-2.168\right)
$$

for P. elongatus (Hay et al. 1988). The copepods in the gut of cod larvae were divided into nauplii, immature copepodites, and mature copepodites, on the basis of their cephalothorax length, using measurements taken from $P$. elongatus. Nauplii were taken as any copepod $<0.42 \mathrm{~mm}$ cephalothorax length, immature copepodites as 0.42 to $0.80 \mathrm{~mm}$ cephalothorax length, and mature copepodites as $>0.80 \mathrm{~mm}$ cephalothorax length. These classifications are approximate, since some overlap in length occurs between categories, but are convenient for the present paper (Hay et al. 1988). The temperature $\left(\mathrm{T},{ }^{\circ} \mathrm{C}\right)$ dependent durations of the nauplii $\left(D_{n}\right)$ and immature copepodite $\left(D_{i}\right)$ stages for $P$. elongatus are given by Thompson (1982) as follows

$$
\begin{array}{ll} 
& \ln D_{n}=3.82-0.116 \mathrm{~T} \\
\text { and } \quad \ln \left(D_{i}+D_{n}\right)=4.64-0.109 T .
\end{array}
$$

\section{RESULTS}

\section{Hydrography}

Average temperatures in the western Irish Sea, for the stations sampled on 24 April to 2 May 1988 and 16 to 20 April 1989 , were 8.6 and $8.2^{\circ} \mathrm{C}$, respectively. Stratification occurred at the centre of the sampling grid in 1988 where surface to bottom temperature differences exceeded $1{ }^{\circ} \mathrm{C}$ (Fig. 1a), but this feature was absent during sampling in 1989.

\section{Copepod and fish larvae densities}

Copepods formed the majority of the zooplankton biomass in the size range eaten by cod larvae, with other components being rather uncommon. The plankton collected by the fine mesh net was composed almost entirely of copepods. The most common genera identified in 1988 were Temora, Pseudocalanus, and Oithona, which were present in similar quantities and collectively formed $68 \%$ of all identified copepods present. Other copepods present were Acartia (12\%), Microcalanus $(10 \%)$, Centropages $(3 \%)$, Calanus $(2 \%)$, and Paracalanus $(<1 \%)$. Harpacticoid copepods $(3 \%)$ and other cyclopoid copepods $(<1 \%)$ were uncommon. Differences in species composition between sampling localities are not presented here.

Densities of nauplii and copepodites ranged from 0 to $89 \mathrm{I}^{-1}$ and 0 to $29 \mathrm{I}^{-1}$ respectively, with average densities being ca 12 nauplii and 5 copepodites $1^{-1}$ in both 1988 and 1989 (Fig. 1a to d). Nauplii and copepodite densities were significantly correlated $(\mathrm{r}=0.77, \mathrm{df}$ $=81, \mathrm{p}<0.01)$. In 1989, an increase in densities was observed to the north of the 1988 distribution, at and around $54^{\circ} \mathrm{N}$ between Ireland and the southern tip of the Isle of Man. Low densities of $<1.0$ nauplii and copepodites $1^{-1}$ were observed in the southeastern sector of the sampling grid in 1989. However, as this area was not sampled in 1988 no comparisons can be made. It is clearly seen in the distributions of nauplii and copepodites, particularly in 1988 , that very great variation in densities can occur over a short distance. The size range of copepods in the fine mesh samples ranged from 0.1 to $1.4 \mathrm{~mm}$ cephalothorax length, with nauplii ranging from 0.1 to $0.4 \mathrm{~mm}$, and copepodites ranging from 0.1 to $1.7 \mathrm{~mm}$ (Fig. 3). Owing to the scarcity of Calanus, there were very few copepods with a cephalothorax length $>1.3 \mathrm{~mm}$. The region of overlap between the nauplii and copepodite stages is the result of combining several species into the length composition. The early copepodite stages of Acartia and Oithona are smaller than Pseudocalanus and account for the extension down to $0.1 \mathrm{~mm}$ of cephalothorax length.

Densities of cod larvae were some 5 orders of magnitude lower than copepod densities and ranged from zero to a maximum of $0.26 \mathrm{~m}^{-3}$ with a mean of $0.03 \mathrm{~m}^{-3}$ (Fig. 1e, f). Cod larvae caught in the calibrated tows ranged from 2 to $20 \mathrm{~mm}$ total length, with an average length of $7 \mathrm{~mm}$ (Fig. 4). Average densities were low, particularly when cod larvae exceeded $12 \mathrm{~mm}$ in length. Other species of fish larvae were very abundant in certain areas, with densities reaching $10.7 \mathrm{~m}^{-3}$ (Fig. $1 \mathrm{~g}, \mathrm{~h}$ ), but were on average $1.7 \mathrm{~m}^{-3}$. Hence, total larvae densities were 60 times the density of cod larvae. However, at some stations, cod larvae formed $10 \%$ of the total larvae present. The most abundant fish larvae

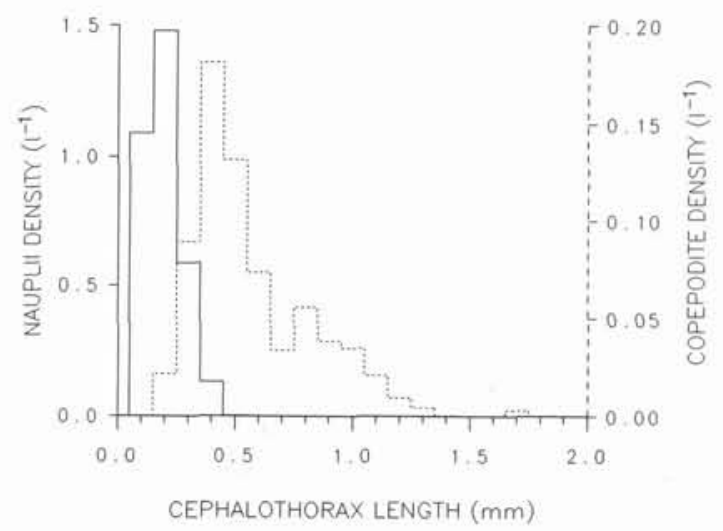

Fig. 3. Average densities of nauplii (continuous line) and copepodite (dashed line) copepods in the western Irish Sea in $0.1 \mathrm{~mm}$ cephalothorax size groups during 1988 
were Limanda limanda $(46 \%, 37 \%)$, clupeids (mainly Sprattus sprattus; $23 \%, 26 \%)$, Callionymus spp. (11\%, $8 \%)$, and rocklings $(6 \%, 5 \% ; 1988$ and 1989 respectively).

\section{Diet of cod larvae}

The 144 cod larvae examined from the collection tows made in the western Irish Sea had fed almost exclusively on motile stages of calanoid copepods, with eggs (probably copepod) and other animal matter occurring in less than $5 \%$ of the individual cod larvae. These were invariably individuals of lamellibranch lar-

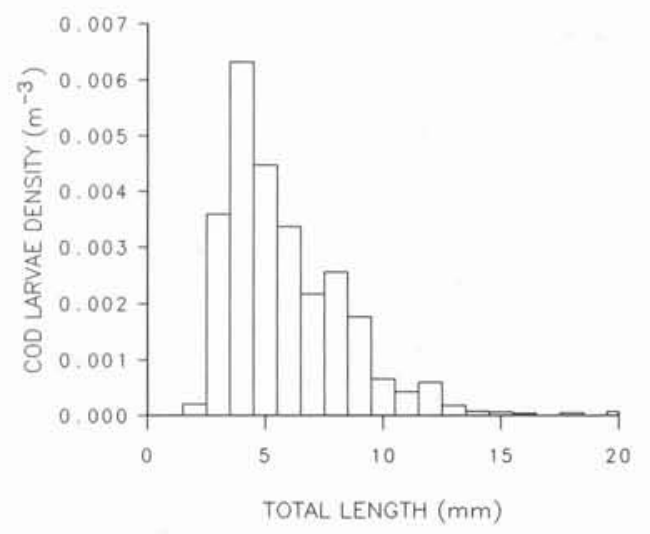

Fig. 4. Gadus morhua. Average length distribution of cod larvae in the western Irish Sea for 1988 and 1989

vae, gastropod larvae, or cladocerans, but their biomass was always small in comparison to copepods present. The size range of copepods eaten is dependent upon the size of the cod larvae. In this study, cod larvae were assigned to one of 3 length groups. The 8 stomachs examined from cod larvae in the $<5 \mathrm{~mm}$ length group contained mainly copepod nauplii with cephalothorax lengths of 0.1 to $0.4 \mathrm{~mm}$, together with some unidentified green matter of presumably phytoplanktonic origin. The 123 cod larvae in the 5 to $9 \mathrm{~mm}$ length group were eating copepods with a cephalothorax length up to $1.2 \mathrm{~mm}$, although most were less than $0.6 \mathrm{~mm}$. Phytoplankton was evident in some of the 5 to $7 \mathrm{~mm}$ larvae. This size range of cod larvae is therefore able to crop immature and mature copepodites of the common species of copepod. The thirteen 10 to $20 \mathrm{~mm}$ cod larvae were eating fewer nauplii and a much higher proportion of immature and mature copepodites (Fig.5). The mean copepod cephalothorax length and dry weight calculated from Eq. (8), in each cod size category, is given in Table 1.

\section{Daily numbers of copepods eaten by cod larvae}

Cod larvae in the Irish Sea were increasing their dry body weight by $10 \% \mathrm{~d}^{-1}$ (K. Brander unpubl.). The dry weight of copepods required to satisfy metabolic requirements was estimated using Eq. (1) with a sea temperature of $8.5^{\circ} \mathrm{C}$. The number of copepods eaten per day is therefore the dry weight eaten per day divided by the average dry weight of a copepod in the diet of each size range of larvae. The $4 \mathrm{~mm}$ larvae required $59 \%$ of their body weight in food $\mathrm{d}^{-1}$, which decreased to $34 \% \mathrm{~d}^{-1}$ for $12.5 \mathrm{~mm}$ larvae. The weight of copepods required by the larvae increased from 70 to $942 \mu \mathrm{g} \mathrm{d}^{-1}$ over the size range examined. However, this increase in food requirement was only partially met by an increase in the numbers eaten which ranged from 156 to $196 \mathrm{~d}^{-1}$. Of more significance was the increased average size of copepod which larger larvae could eat. The mean dry weight of individual copepods in the stomachs of the largest size class of cod larvae examined was over 10 times greater than for the smallest larvae (Table 1).
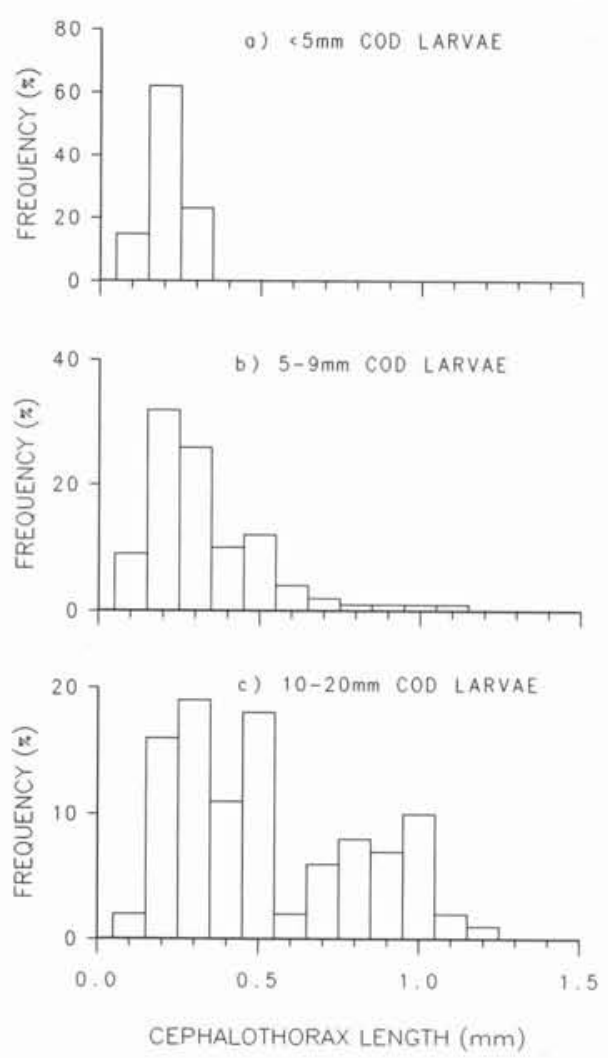

Fig. 5. Length-frequency composition of copepods found in the stomachs of 3 size categories of cod Gadus morhua larvae in the western Irish Sea for 1988 and 1989 
Table 1. Parameters used in the feeding model (Eq. 1) and predictions of weight and number of copepods eaten at $8.5^{\circ} \mathrm{C}$. The daily increase in weight of a cod Gadus morhua larva $\left(\Delta \mathrm{W}_{\mathrm{L}}\right)$ requires $\mathrm{R}$ copepods of total dry weight $\mathrm{W}_{\mathrm{F}}$ to fulfil its energy requirements for anabolic and catabolic processes

\begin{tabular}{|c|c|c|c|c|c|}
\hline $\begin{array}{l}\text { Length of } \\
\text { larva }\end{array}$ & $\begin{array}{c}\text { Mean dry wt } \\
\text { (and cephalothorax } \\
\text { length) of copepod } \\
\text { in stomach } \\
\mu \mathrm{g}(\mathrm{mm})\end{array}$ & $\begin{array}{l}\text { Dry wt } \\
\text { of cod } \\
\text { larva } \\
\mu g\end{array}$ & $\Delta W_{L}$ & $\begin{array}{l}\text { Wt of } \\
\text { copepods } \\
\text { eaten } d^{-1} \\
\mu \mathrm{g}\end{array}$ & $\begin{array}{l}\text { No. of } \\
\text { copepods } \\
\text { eaten } d^{-1} \\
\text { R }\end{array}$ \\
\hline 4 & $\begin{array}{c}0.434 \\
(0.26)\end{array}$ & 119 & 12 & 69.7 & 161 \\
\hline 7.5 & $\begin{array}{r}1.820 \\
(0.56)\end{array}$ & 679 & 68 & 283.6 & 156 \\
\hline 12.5 & $\begin{array}{c}4.801 \\
(0.75)\end{array}$ & 2800 & 280 & 942.4 & 196 \\
\hline
\end{tabular}

Table 2. Predicted numbers of copepods required by a single cod Gadus morhua larva in the western Irish Sea at $8.5^{\circ} \mathrm{C}$ and $10 \%$ $\mathrm{d}^{-1}$ growth rate, and steady state densities of copepods to support $1 \mathrm{cod}$ larva $\mathrm{m}^{-3}$. Values are given for 3 lengths of cod larvae $(4,7.5$ and $12.5 \mathrm{~mm})$

\begin{tabular}{|c|c|c|c|c|c|c|c|c|c|c|c|c|c|c|c|}
\hline \multirow[t]{2}{*}{ Copepod stage } & \multicolumn{3}{|c|}{$\begin{array}{l}\text { Average copepod } \\
\text { cephalothorax } \\
\text { length in diet } \\
\text { of } \operatorname{cod}(\mathrm{mm})\end{array}$} & \multicolumn{3}{|c|}{$\begin{array}{l}\text { Average dry wt } \\
\text { of copepod in } \\
\text { diet of cod } \\
(\mu \mathrm{g})\end{array}$} & \multicolumn{3}{|c|}{$\begin{array}{c}\text { Frequency of } \\
\text { occurrence } \\
\text { in diet } \\
(\%)\end{array}$} & \multicolumn{3}{|c|}{$\begin{array}{l}\text { No. eaten per cod } \\
\mathrm{d}^{-1}\end{array}$} & \multicolumn{3}{|c|}{$\begin{array}{l}\text { Steady state } \\
\text { density of } \\
\text { copepods } \\
1^{-1} \text { at } 1 \text { cod } \mathrm{m}^{-3}\end{array}$} \\
\hline & 4 & 7.5 & 12.5 & 4 & 7.5 & 12.5 & 4 & 7.5 & 12.5 & 4 & 7.5 & 12.5 & 4 & 7.5 & 12.5 \\
\hline Nauplii & 0.26 & 0.27 & 0.30 & 0.43 & 0.46 & 0.52 & 100 & 68 & 42 & 161 & 106 & 82 & 0 & 0.85 & 1.94 \\
\hline Immature copepodite & - & 0.54 & 0.55 & - & 1.88 & 1.94 & 0 & 27 & 31 & 0 & 42 & 61 & 0 & 0.19 & 1.27 \\
\hline Mature copepodite & - & 1.00 & 0.94 & - & 20.21 & 14.61 & 0 & 5 & 27 & 0 & 8 & 53 & 0.16 & 0.16 & 0.20 \\
\hline Total copepods & & & & & & & & & & 161 & 156 & 196 & 0.16 & 1.20 & 3.41 \\
\hline
\end{tabular}

\section{Standing stocks of copepods which support cod and other larvae}

Estimated standing stock densities of copepods which can support single larva on a sustainable basis were calculated from Eq. (6) and information given in Table 2. The standing stock density given is where recruitment to the copepod population is balanced by the copepods which are eaten by fish larvae. This can be viewed as an equilibrium level under the conditions defined by the models, and is given in Table 2 .

At a $10 \%$ growth rate, a population of 0.16 mature copepodites $\mathrm{I}^{-1}$ could support one $4 \mathrm{~mm}$ cod larva $\mathrm{m}^{-3}$. No nauplii are actually required in the standing stock, since small cod larvae graze on nauplii only and the sexually reproducing mature copepodites alone can provide these. In this case, nauplii production is exactly balanced by nauplii predation. In practice, a small number of nauplii will be observed since a time delay will occur between production and predation. This is not the case for $7.5 \mathrm{~mm}$ cod at a density of $1 \mathrm{~m}^{-3}$, which require a standing stock of 1.20 copepods $1^{-1}$, many of which must be nauplii. There is then a dramatic increase in the standing stock required to support a $12.5 \mathrm{~mm}$ cod larvae $\mathrm{m}^{-3}$ to 3.41 copepods $1^{-1}$. Nauplii must, in this case, comprise about one half of the copepod population, to replenish the copepodites that are eaten and also to serve as a direct source of food. This shows that the standing stock of copepods required to satisfy the food requirements of growing larvae increases at a greater rate than would be expected if only food requirements were considered.

Food requirements of cod larvae at densities other than $1 \mathrm{~m}^{-3}$ are estimated by multiplying the cod larvae density by the copepod standing stock estimates. The maximum density of cod larvae in 1988/1989 was $0.26 \mathrm{~m}^{-3}$, which was composed of $29 \%$ of larvae $<5 \mathrm{~mm}, 68 \% 5$ to $9 \mathrm{~mm}$, and $3 \%>10 \mathrm{~mm}$. According to the model's predictions, these cod larvae would require a standing stock of 0.26 copepods $1^{-1}$. Most stations in the western Irish Sea had densities of copepods well above this level, especially in areas where cod larvae were present. Therefore, in the absence of any other species of larvae, it can be seen that densities of copepods are high enough to amply satisfy the food requirement of cod larvae. 
Unpublished studies by the authors have shown that the diets of the other species of fish larvae examined in the Irish Sea were similar to cod larvae. Therefore, some degree of inter-specific competition may occur when food is limiting. Hence, the abundance of 'noncod' larvae is likely to be important in determining the dynamics of cod larvae. At average total larvae densities of $1.7 \mathrm{~m}^{-3}$ it seems unlikely that fish larvae would control copepod densities. At high fish larvae dénsities of $>10 \mathrm{~m}^{-3}$, copepod standing stocks of ca $151^{-1}$ are required, if they are assumed to have the same requirements and growth rates as $7.5 \mathrm{~mm}$ cod larvae. These copepod densities are towards the upper limit of those which are normally encountered in the Irish Sea and so competition between fish larvae may be expected in some areas.

\section{Search ability of larvae and interactions with food requirements}

The above predictions, regarding the standing stock of copepods to satisfy the energy requirements of lar- vae, fail to account for the ability of larvae to search and detect food. Assuming cod larvae can search the same volume of water per day as haddock larvae, then 4, 7.5, and $12.5 \mathrm{~mm}$ cod larvae would be able to search 10, 76, and $2581 \mathrm{~d}^{-1}$, respectively (Laurence 1982, Cushing 1983). These sizes of larvae require 161, 156 and 196 copepods $\mathrm{d}^{-1}$, respectively, to satisfy their metabolic requirements (Table 1 ). If it is assumed that larvae eat all the copepods they encounter, then the minimum copepod densities that must exist to satisfy these search requirements would be $16.9,2.1$, and $0.81^{-1}$ for $4,7.5$ and $12.5 \mathrm{~mm}$ cod larvae, respectively (Fig. 6, dashed line). Hence, higher copepod densities are required to support small larvae than are needed for larger larvae based on their ability to find food. If, as Beyer (1980) found, larvae eat only a proportion of the copepods which they encounter, then these densities would increase accordingly. The continuous line on Fig. 6 defines the equilibrium position for the copepod standing stock under predation by fish larvae at a $10 \%$ daily growth rate. Above this line lies the region where food is predicted to be in excess of dietary requirements of larvae. However, the area below the line represents the a) $4 \mathrm{~mm}$ larvae

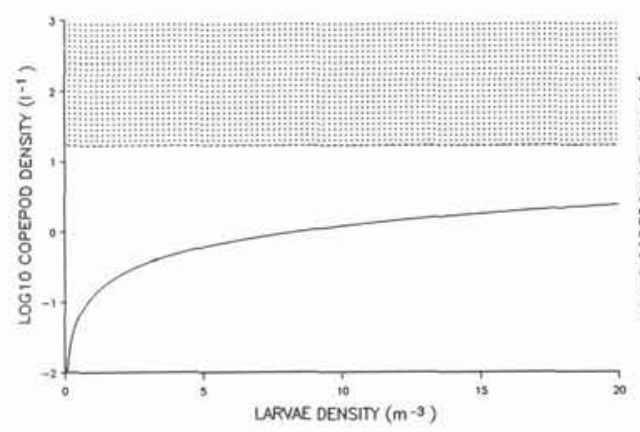

c) $12.5 \mathrm{~mm}$ larvae

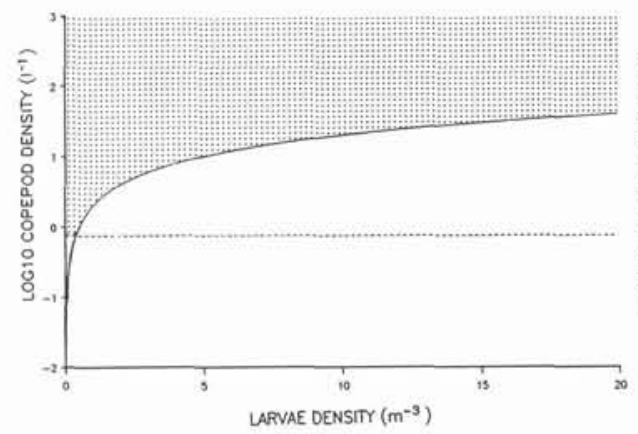

b) $7.5 \mathrm{~mm}$ larvae

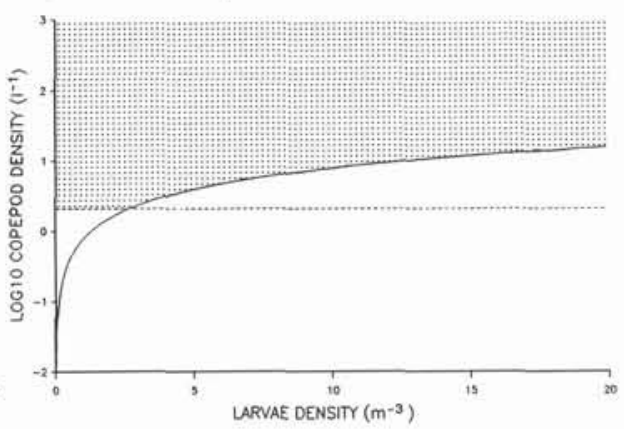

d) Observed densities

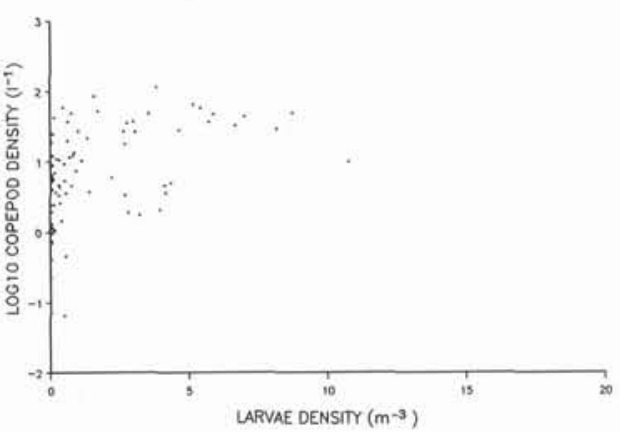

Fig. 6. (a) to (c) Predicted densities of copepods required to support fish larvae of (a) $4 \mathrm{~mm}$ length, (b) $7.5 \mathrm{~mm}$ length, and (c) $12.5 \mathrm{~mm}$ length (stippled area), over a range of densities. Copepod density must be above a threshold value determined by the daily energy requirement of a larva (continuous line) and the volume of water searched per day (dashed line). The copepods must also be sufficiently abundant to be able to replace those eaten by the fish larvae population. The predicted steady state copepod density occurs when copepod reproduction is balanced by predation from the fish larvae population (continuous line). See text for details. (d) Densities of copepods and fish larvae (all species) observed in the western Irish Sea in 1988 and 1989. Larvae densities are for all lengths combined, and mostly fall in the predicted regions of survival given for 4 to $12.5 \mathrm{~mm}$ larvae (a) to (c) 
region where food is likely to be limiting and a reduction in larvae growth rate or numbers is predicted. It is seen that the search efficiency and the energy budget models predict different constraints on the copepod densities required to support larvae of a given size (Fig. 6, continuous and dashed lines). Clearly, both constraints must be satisfied for survival of the larvae (Fig. 6, stippled area).

Densities of copepods and fish larvae of all species in the western Irish Sea, for the stations sampled in 1988 and 1989, are shown on Fig. 6d. These data have not been divided into separate fish larvae size categories, as detailed information on the lengths of all species of larvae were not available. However, the average length of 352 larvae, randomly selected from the 1988 samples, was $8.6 \mathrm{~mm}$ with $70 \%$ being less than $10 \mathrm{~mm}$ in length. This indicates that the points are best approximated to the plot for $7.5 \mathrm{~mm}$ larvae (Fig. 6b), but that certain stations will have larvae that fit more readily into other size categories (Fig. 6a, c). Nevertheless, the models presented do show approximate agreement with many of the observed densities of fish larvae and copepods. However, there are observed densities that fall outside the stippled area, particularly at low larvae and copepod densities.

\section{DISCUSSION}

The densities of copepod nauplii and copepodites found in this study were approximately 2 to 3 times the densities found by Scrope-Howe \& Jones (1985) in May 1981 for the western Irish Sea. Both studies show an increased density of copepods in the waters which are, or have become, stratified and occur to the northwest of the western Irish Sea front. This increased density was not necessarily entirely attributable to stratification, since the onset of stratification was delayed in 1989, with no apparent reduction in copepod densities over 1988. The species composition of the Copepoda, determined for 1988 only, was similar to that found by Scrope-Howe \& Jones (1985) in 1981, when Pseudocalanus, Acartia, Oithona, Temora, and Microcalanus formed $96.4 \%$ of the copepods present, but Calanus formed only $3.2 \%$. However, Scrope-Howe \& Jones (1985) recorded a different species composition in 1980 when Calanus formed $17.4 \%$ of the copepod numbers. As noted by Bollens (1988), a switch from a 'small' copepod dominated system to a 'large' Calanus dominated system can substantially alter the population dynamics of the copepods under predatory attack. Cod and other species of fish larvae were more abundant close to the Irish coast, where copepod populations were also generally more abundant. Few copepods or fish larvae were found in the southeastern sector of the sampling grid in 1988 or 1989.

The diet of cod larvae found in this study was similar to that reported by Last (1982). The smallest cod larvae feed on copepod nauplii with some supplementation of their diet with phytoplankton, which appeared as homogeneous green matter in the gut. Cod larvae over $5 \mathrm{~mm}$ in length rarely contained phytoplankton, and copepods assumed a greater importance. The energetic model used in this paper assumed that all energy requirements were met by this diet. The model used to predict standing stocks of copepods that are required to support larvae on a sustainable basis is based on Bollens (1988). However, the additional $6 \%$ daily mortality, above that due to fish predation, was not included in the model. This would have the effect of increasing estimated standing stocks estimated by the equilibrium states (Eq. 6). As an approximate guide, steady state standing stocks would increase by 2 to 3 fold if an additional $6 \%$ daily copepod mortality was included. Additionally, this model assumed an equal sex ratio in all stages, which results in an underestimation of copepod densities of $30 \%$ or more in situations when adult females predominate (Bogorov 1939, Marshall \& Orr 1955).

The models used in this paper simplify many biological processes into a few equations, but still capture the underlying dynamics (see Checkley 1984, Kiørboe et al. 1987, Bollens 1988). The use of steady-state or equilibrium solutions to predict the densities of copepods required to support various densities of larvae assumes that population parameters, such as food requirements and fecundity, are not changing too rapidly. This assumption is likely to be reasonable for the fish larvae and copepod system described here, particularly since the copepod Pseudocalanus sp. does not show rapid fluctuations in fecundity in response to varying food supply, as is seen for the larger copepods, e.g. Calanus pacificus (Frost 1985). The energetic model used in this paper predicted daily rations of 59 to $34 \%$ of body weight for the 4 to $12.5 \mathrm{~mm}$ cod larvae. This was acquired by the cod consuming 156 to 196 copepods $\mathrm{d}^{-1}$, which is within the ranges of daily rations given by Theilacker \& Dorsey (1980). The model is therefore predicting values that are supported by other studies on various species of fish larvae. Feeding studies on early stage Arcto-Norwegian cod larvae showed that 5 to 10 nauplii $1^{-1}$ are needed for adequate feeding levels, and this may form a critical lower density for survival under natural conditions (Ellertsen et al. 1984, 1987). These densities compare favourably with the prediction of 16.9 copepods $1^{-1}$ estimated from the volume of water which a $4 \mathrm{~mm}$ cod can search per day. Furthermore, Ellertsen et al. (1987) found that 'micro-patches' of high densities of nauplii formed under calm sea conditions, which enhanced the feed- 
ing ability of the cod larvae. These 'micro-patches' disappeared under turbulent conditions, causing mixing and the elimination of high density patches of nauplii, which resulted in a reduced feeding rate. Heath (1989) examined the influence of wind stress and light intensity on the feeding success and vertical distribution of herring larvae, and showed 2 to 3 fold differences in feeding success. Thus, many factors, outside of food abundance, can affect feeding success and hence the growth of larvae.

The maximum density of cod larvae observed in the western Irish Sea was $0.26 \mathrm{~m}^{-3}$, with their sizes ranging from 3 to $11 \mathrm{~mm}$. From the model, it is estimated that only 0.26 copepods $1^{-1}$ are needed for survival of these cod larvae on a sustained basis. However, since all species of fish larvae examined from the western Irish Sea, from samples taken in April/May 1988 and 1989, had a similar diet (A. B. Thompson \& R. T. Harrop unpubl.) then cod will be competing with other fish species, and also probably with invertebrate predators, for food (Fortier \& Harris 1989). The system must then be viewed at a multispecies level, especially as cod formed less than $2 \%$ of total larvae numbers present. The consequence of this is apparent when examining the interaction between volumes searched and copepod densities required to satisfy energy requirements (Fig. 6). The assumption here is that all larvae species have the same energetic requirements as cod, and so the demands of the fish larvae population can be estimated. Individual $4 \mathrm{~mm}$ larvae require only 0.16 copepods $1^{-1}$ (albeit within a specific size range, viz. nauplii) to support their energy requirements at a $10 \%$ daily growth rate (Table 2), but as they can only search a small volume of water the copepod density needs to be higher. For the $4 \mathrm{~mm}$ larvae to find their 161 nauplii $\mathrm{d}^{-1}$, a density of 17 copepods $\mathrm{l}^{-1}$ is required, although this could support ca 100 larvae $\mathrm{m}^{-3}$. The slightly larger $7.5 \mathrm{~mm}$ larvae can search a larger volume of water, and so the minimum density to support larvae of this size is 2 copepods $1^{-1}$. This would support between one and two $7.5 \mathrm{~mm}$ larvae $\mathrm{m}^{-3}$. When larvae are $12.5 \mathrm{~mm}$ in length, their search ability is such that a single larva $\mathrm{m}^{-3}$ can satisfy their energy requirements at densities of 0.7 copepods $1^{-1}$. However, at this density the copepod population would soon be eaten out, as Eq. (6) estimates that 3.4 copepods $1^{-1}$ are required to support one $12.5 \mathrm{~mm}$ larva $\mathrm{m}^{-3}$ on a sustained basis (Fig. $6 \mathrm{c}$ ). It is at these larger sizes that competition for food is expected to occur.

Beyer \& Lawrence (1980) proposed that a $3 \%$ daily growth rate was required in order for larvae to survive, and this could be used in the model to estimate minimum copepod densities required by larvae to avoid starvation mortality. Under these conditions, the predicted daily energy requirements and standing stock copepod densities are reduced by 24 to $42 \%$, with the greatest reduction occurring in the larger larvae. However, as the model does not allow for dynamic interactions between fish larvae densities, fish larvae growth rates and copepod densities, it is not possible to examine these aspects further.

When Cushing (1969) proposed his match-mismatch hypothesis he assumed that 'baby fish' subsist mainly on copepod nauplii. This is certainly the case for the cod larvae examined in this study. However, the models suggest that nauplii are rarely dense enough to satisfy daily energy requirements of $<5 \mathrm{~mm}$ larvae given the latter's limited searching ability. Therefore, phytoplankton may be an important supplement to the diet of small larvae, especially since densities of nauplii as high as $171^{-1}$ were seen at only 21 of 83 stations sampled in this study. Larger larvae move onto copepodite stages as their gape increases, and these must be present at high densities to maintain a continuing supply of food when predation pressure is high. As stated above, individual $12.5 \mathrm{~mm}$ larvae require densities of copepods of $3.41^{-1}$, and this was observed at 39 of 83 stations sampled. However, to support ten $12.5 \mathrm{~mm}$ larvae requires 48 copepods $1^{-1}$, and this was observed at only 2 of 83 stations. It seems that there are many different stages in the early life history of larvae that must be blessed with favourable conditions in order to ensure adequate survival. Within the framework and assumptions of the model used, the 2 questions proposed in the 'Introduction' have been answered. However, it does appear that phytoplankton is likely to be very important in the first few days of a larva's life, and was found in the intestines of small cod larvae. It is known that phytoplankton is subject to rapid and rather unpredictable blooms (Harris 1986), and could be the cause of high and unpredictable early fish larvae mortality.

Acknowledgements. We thank J. Horwood, K. Brander and the referees for their constructive comments on the manuscript.

\section{LITERATURE CITED}

Beyer, J. E. (1980). Feeding success of clupeoid fish larvae and stochastic thinking. Dana 1: 65-91

Beyer, J. E., Laurence, G. C. (1980). A stochastic model of larval growth. Ecol. Modelling 8: 109-112

Boehlert, G. W., Yoklavich, M. M. (1984). Carbon assimilation as a function of ingestion rate in larval Pacific herring, Clupea harengus pallasi Valenciennes. J. exp. mar. Biol. Ecol. 79: 251-262

Bogorov, B. G. (1939). Sex ratio in marine copepods. C. R. (Dokl.) Acad. Sci. URSS 23: 706-709

Bollens, S. M. (1988). A model of the predatory impact of larval marine fish on the population dynamics of their zooplankton prey. J. Plankton Res. 10: 887-906 
Brett, J. R., Groves, T. D. D. (1979), Physiological energetics. in: Hoar, W. S., Randall, D. J., Brett, J. R. (eds.) Fish physiology, Vol. VIII. Bioenergetics and growth Academic Press, New York, p. 279-352

Buckley, L. J., Dillmann, D. W. (1982). Nitrogen utilization by larval summer flounder, Paralichthys dentatus (Linnaeus). J. exp. mar. Biol. Ecol. 59: 243-256

Checkley, D. M. (1984). Relation of growth to ingestion for larvae of Atlantic herring Clupea harengus and other fish. Mar. Ecol. Prog. Ser. 18: 215-224

Cushing, D. H. (1969). The fluctuation of year-classes and the regulation of fisheries. FiskDir. Skr. (Ser. HavUnders.) 15: 368-379

Cushing, D. W. (1983). Are fish larvae too dilute to affect the density of their food organisms? J. Plankton Res. 5: 847-854

Dagg, M. J., Clarke, M. E., Nishiyama, T., Smith, S. L. (1984). Production and standing stock of copepod nauplii, food items for larvae of the walleye pollack Theragra chalcogramma in the southeastern Bering Sea. Mar. Ecol. Prog. Ser. 19: 7-16

Ellertsen, B., Fossum, P., Solemdal, P., Sundby, S., Tilseth, S. (1984). A case study on the distribution of cod larvae and availability of prey organisms in relation to physical processes in Lofoten. In: Dahl, E., Danielssen, D. S., Moksness, E., Solemdal, P. (eds.) The propogation of cod Gadus morhua L. Flødevigen rapportser. 1: 453-477

Ellertsen, B., Fossum, P., Solumdal, P., Sundby, S., Tilseth, S. (1987). The effect of biological and physical factors on the survival of Arcto-Norwegian cod and the influence on recruitment variability. In: Loeng, $H$. (ed.) The effect of oceanographic conditions on distribution and population dynamics of commercial fish stocks in the Barents Sea. Proceedings of the third Soviet-Norwegian symposium Murmansk, 26-28 May 1986. Institute of Marine Research, Bergen, Norway, p. 101-126

Fogg, G. E., Egan, B., Hoy, S., Lochte, K., Scrope-Howe, S., Turley, C. M. (1985). Biological studies in the vicinity of a shallow-sea tidal mixing front I. Physical and chemical background. Phil. Trans. R. Soc. Lond. B 310: 407-433

Fortier, L., Harris, R. P. (1989). Optimal foraging and densitydependent competition in marine fish larvae. Mar. Ecol. Prog. Ser. 51: 19-33

Frost, B. W. (1985). Food limitation of the planktonic marine copepods Calanus pacificus and Pseudocalanus sp. in a temperate fjord. Arch. Hydrobiol. Beih. Ergebn. Limnol. 21: $1-13$

This article was submitted to the editor
Harris, G. P. (1986). Phytoplankton ecology structure, function and fluctuation. Chapman and Hall, London

Hay, S. J., Evans, G. T., Gamble, J. C. (1988), Birth, growth and death rates for enclosed populations of calanoid copepods. J. Plankton Res. 10: 431-454

Heath, M. (1989). A modelling and field study of grazing by herring larvae. Rapp. P.-v. Réun. Cons, int. Explor, Mer 191: 233-247

Kiørboe, T., Munk, P., Richardson, K. (1987). Respiration and growth of larval herring Clupea harengus: relation between specific dynamic action and growth efficiency. Mar. Ecol. Prog. Ser. 40: 1-10

Last, J. M. (1982). The food of twenty species of fish larvae in the west-central North Sea. Fish. res. Tech. Rep., MAFF Direct. Fish. Res., Lowestoft 60, p. 1-44

Laurence, G. C. (1978). Comparative growth, respiration and delayed feeding abilities of larval cod (Gadus morhua) and haddock (Melanogrammus aeglefinus) as influenced by temperature during laboratory studies. Mar. Biol. 50: 1-7

Laurence, G. C. (1982). Nutrition and trophodynamics of larval fish - review, concepts, strategic recommendations and opinions. Univ. Miami. Tech. Rep. No. 82008, p. 123-171

Marshall, S. M., Orr, A. P. (1955). The biology of a marine copepod. Oliver \& Boyd, Edinburgh

Milligan, S. P., Riches, B. F. (1983). The new MAFF/Guildline high speed plankton sampler. Comm. Meet. int. Coun. Explor. Sea. C. M. ICES L:7,1-5 (mimeo)

Nichols, J. H., Thompson, A. B. (1990). Mesh selection of copepodite and nauplius stages of four calanoid copepod species. J. Plankton Res. (in press)

Peterson, W. T., Ausubel, S. J. (1984). Diets and selective feeding by larvae of Atlantic mackerel Scomber scombrus on zooplankton. Mar. Ecol. Prog. Ser. 17: 65-75

Scrope-Howe, S., Jones, D. A. (1985). Biological studies in the vicinity of a shallow-sea tidal mixing front $\mathrm{V}$. Composition, abundance and distribution of zooplankton in the western Irish Sea, April 1980 to November 1981. Phil. Trans. R. Soc. Lond. B 310: 501-519

Theilacker, G., Dorsey, K. (1980). Larval fish diversity, a summary of laboratory and field research. In: Sharp, G. (rapporteur), Workshop on the effects of environmental variation on the survival of larval pelagic fishes. UNESCO, Intergovernmental Oceanographic Commission, Workshop Report 28, p. 105-142

Thompson, B. M. (1982). Growth and development of Pseudocalanus elongatus and Calanus sp, in the laboratory. J. mar. biol. Ass. U.K. 62: 359-372

Manuscript first received: June 20, 1990

Revised version accepted: September 12, 1990 